PRACE GEOGRAFICZNE

zeszyt 158, 2019, 45-64

doi: 10.4467/20833113PG.19.015.10919

Instytut Geografii i Gospodarki Przestrzennej UJ

Komisja Geograficzna, Polska Akademia Umiejętności

Wydawnictwo Uniwersytetu Jagiellońskiego

\title{
ZASTOSOWANIE TECHNOLOGII INFORMACYJNO-KOMUNIKACYJNYCH W PROMOCJI I INFORMACJI TURYSTYCZNEJ NA PRZYKŁADZIE GMIN WOJEWÓDZTWA MAŁOPOLSKIEGO
}

\author{
Aneta Pawtowska-Legwand
}

\section{Use of ICT in promotion and tourist information of communes in Lesser Poland Voivodeship}

\begin{abstract}
Information and communication technology allows for new, more interactive ways of promotion activities and tourist information presentation. Dissemination of broadband Internet and mobile devices as well as development of new programming technologies are main driving forces for broader use of tools such as mobile applications, social media, augmented and virtual reality. Territorial governments and most of all local governments use this potential in executing their tasks in the area of promotion and tourist information established by law regulations. The main goal of this paper was to present research results focused on activities in the area of promotion and tourist information where information and communication technology was implemented by local governments in communes of Lesser Poland Voivodeship. Collecting data about selected digital tools was conducted in 2013 and 2018 for 182 communes. Qualitative and quantitative analysis was performed on obtained database according to a set of criteria. Then, range and directions of activities were characterized and estimated. On this basis, activities realized by local governments in the research area can be described as numerous and various. Among examples of activities are modernization of official websites of commune offices, creation of next mobile applications, also with QR codes and beacon technology, and growing activity in social media.
\end{abstract}


Keywords: information and communication technology, promotion, tourist information, local government, Lesser Poland Voivodeship

Zarys treści: Technologie informacyjno-komunikacyjne umożliwiają realizowanie działań promocyjnych i przekazywanie informacji turystycznej w nowy, multimedialny i interaktywny sposób. Upowszechnienie się dostępu do szerokopasmowej sieci internetowej i urządzeń przenośnych oraz rozwój technologii programistycznych sprzyjają z kolei podejmowaniu tych działań na szerszą skalę i za pośrednictwem takich narzędzi, jak aplikacje mobilne, media społecznościowe oraz rzeczywistość rozszerzona i wirtualna. Samorządy terytorialne, w tym przede wszystkim samorządy gminne, realizujące działania z zakresu promocji i informacji turystycznej w ramach zadań wskazanych w aktach prawnych, korzystają z tego potencjału. Celem artykułu było przedstawienie wyników badań dotyczących działań związanych z promocją i informacją turystyczną, zrealizowanych z zastosowaniem technologii informacyjno-komunikacyjnych przez samorządy gminne w województwie małopolskim. W 2013 r. i 2018 r. przeprowadzono inwentaryzację wybranych narzędzi cyfrowych dla 182 gmin. Zestawienie to przeanalizowano w ujęciu ilościowym i jakościowym według przyjętych kryteriów, co umożliwiło charakterystykę oraz ocenę zakresu i kierunków działań. Na tej postawie można powiedzieć, że samorządy gminne zrealizowały liczne i zróżnicowane zadania w tym zakresie. Jest to widoczne na przykładzie modernizowania oficjalnych stron internetowych, udostępniania kolejnych aplikacji mobilnych, także z QR kodami lub technologią beacon, i systematycznego zwiększania aktywności w mediach społecznościowych.

Stowa kluczowe: technologie informacyjno-komunikacyjne, promocja, informacja turystyczna, samorząd gminny, województwo małopolskie

\section{Wprowadzenie}

Promocja jest jednym z zadań władz lokalnych wskazanych w Ustawie z dnia 8 marca 1990 r. o samoræq̨dzie gminnym i łączy się ona z informacją turystyczną. Zadania te są coraz częściej realizowane z wykorzystaniem technologii informacyjno-komunikacyjnych.

Celem artykułu było przedstawienie wyników badań obejmujących diagnozę wykorzystania technologii informacyjno-komunikacyjnych w promocji i informacji turystycznej przez samorządy gminne w województwie małopolskim. Badania przeprowadzono w ramach rozprawy doktorskiej. Zmierzając do rozpoznania zakresu oraz kierunków zrealizowanych działań, dążono do odpowiedzi na postawione pytania badawcze koncentrujące się na zagadnieniach związanych z zastosowaniem narzędzi cyfrowych w sferze promocyjno-informacyjnej polityki turystycznej samorządu gminnego. Dotyczyły one użyteczności oficjalnych stron internetowych urzędów gmin, z uwzględnieniem zakresu udostępnionej na nich informacji turystycznej oraz zróżnicowania narzędzi cyfrowych, m.in. aplikacji mobilnych z informacją turystyczną o gminach. 
Jako podstawowe narzędzie można wskazać oficjalną stronę internetową urzędu gminy, jednak obecnie są stosowane również inne, coraz bardziej zróżnicowane rozwiązania w promocji i informacji turystycznej, z których mogą skorzystać osoby odwiedzające gminę. Są one dostępne w przestrzeni internetowej, czego przykładami są tematyczne serwisy internetowe, konta w mediach społecznościowych i wirtualne spacery, a także w przestrzeni turystycznej, wśród których można wymienić aplikacje mobilne, w tym różnorodne rozwiązania z QR kodami, technologią NFC lub Bluetooth z nadajnikami beacon.

\section{Promocja i informacja turystyczna w zadaniach samorządu terytorialnego}

Zadania realizowane przez samorząd terytorialny na poziomie lokalnym i regionalnym mają kluczowe znaczenie dla rozwoju funkcji turystycznej (Pawlusiński 2005; Filipiak i in. 2010; Kowalczyk 2010; Panasiuk 2010; Borzyszkowski 2012; Mika 2014). Transformacja ustrojowa z przełomu lat 80. i 90. XX w. przyczyniła się do zwiększenia ich samodzielności w tym zakresie (Pawlusiński 2005; Borzyszkowski 2012). Decentralizacja sprzyja realizacji polityki turystycznej (Alejziak 2004), a zakres zadań wyznaczają cele przyjęte w lokalnych i regionalnych strategiach rozwoju, co dotyczy też promocji i informacji turystycznej. Władze samorządowe, we współpracy z innymi podmiotami gospodarki lokalnej lub regionalnej, posługując się atrybutami takimi jak konkurencyjność, przedsiębiorczość i innowacyjność, mogą efektywnie zarządzać rozwojem turystyki (Kornak i in. 2001). Kompetencje władzy lokalnej umożliwiają jej oddziaływanie na przebieg i rozkład przestrzenny ruchu turystycznego przez planowanie i programowanie rozwoju turystyki (Mika 2014), które powinny poprzedzać działania o charakterze diagnostycznym (Kornak i in. 2001) i prognostycznym (Alejziak 2004). Źródło siły władz lokalnych znajduje się w prawnie określonych możliwościach realizowania zmian jakościowych, które mogą zwiększyć wartość użytkową (użyteczność) przestrzeni turystycznej i przez to wyróżnić ją wśród konkurencji (Mika 2014). Wśród narzędzi, za pośrednictwem których samorządy lokalne oddziałują na gospodarkę turystyczną, są narzędzia informacyjne, w tym promocyjne (Pawlusiński 2005).

Rosnąca konkurencja między ośrodkami turystycznymi powoduje konieczność zintensyfikowania działań marketingowych (Merski i in. 2008). Obecnie instrumenty marketingu mix 4P (ang. product, price, placement, promotion), po dostosowaniu do specyfiki działalności samorządu, są wykorzystywane w marketingu terytorialnym przez podmioty publiczne (Bosiacki 2004; Szromnik 2010). W tym ujęciu terytorium jest postrzegane jako „megaprodukt” złożony z „subproduktów”, np. z produktu turystycznego. Możliwości wykorzystania narzędzi takich jak cena i dystrybucja są 
tu ograniczone, natomiast kluczowe znaczenie ma promocja, której formą są public relations. Zadania z zakresu marketingu terytorialnego, razem z indywidualną percepcją i nieformalnymi przekazami informacyjnymi, kształtują wizerunek miejsca (Szromnik 2010). W gospodarce turystycznej komunikowanie się obszaru (miejscowości, regionu, kraju) z odbiorcami rynkowymi odbywa się przede wszystkim przez instrumenty promocji (Altkorn 1998). Rozpowszechnianie pozytywnych, aktualnych i rzetelnych informacji o walorach turystycznych miejscowości i regionów jest celem zarówno realizowania działań promocyjnych, jak i świadczenia informacji turystycznej (Merski i in. 2008). W szerszym ujęciu łączy się to ze wspomnianym wcześniej marketingiem terytorialnym i budowaniem wizerunku miejscowości, gmin i regionów (Glińska i in. 2009; Szromnik 2010).

Efektywne zarządzanie rozwojem turystyki wymaga planowania, koordynowania i finansowania przez podmioty sektora publicznego, zarówno administracji rządowej, jak i samorządów terytorialnych, również we współpracy ponadlokalnej i ponadregionalnej (Holloway 1994; Kornak i in. 2001; Denek 2002; Alejziak 2004; Kowalczyk 2010; Panasiuk 2010; Borzyszkowski 2012; Mika 2014). Przykładem jest utworzenie systemu informacji turystycznej przez podmioty bezpośredniej i pośredniej gospodarki turystycznej (Panasiuk 2010). Zadania te mogą być realizowane przez samorządy terytorialne samodzielnie lub we współpracy poziomej (władze gminne, społeczność) oraz pionowej (władze gminne, powiatowe, wojewódzkie) (Filipiak i in. 2010), np. w ramach organizacji turystycznej lub partnerstwa terytorialnego, także publiczno-prywatnego (Merski i in. 2008; Panasiuk i in. 2010; Borzyszkowski 2012). Patrząc szerzej, zarządzaniu rozwojem społeczno-gospodarczym sprzyjają: orientacja innowacyjna, środki finansowe (budżetowe lub zewnętrzne) i kompetentni liderzy lokalni (Bartkowski i in. 1990; Brol 2009; Hjalager 2010; Mika 2014) oraz zarządzanie strategiczne i marketing terytorialny (Markowski i in. 2005; Szromnik 2010).

Zastosowanie technologii informacyjno-komunikacyjnych jest przykładem orientacji innowacyjnej w promocji i informacji turystycznej. Zakres ich zastosowania systematycznie zwiększa się w zadaniach realizowanych przez podmioty zarządzające rozwojem turystyki, np. samorządy terytorialne (Holloway 1994; Gaworecki 2007; Buhalis 2008; Merski in. 2008; Buhalis i in. 2011). Upowszechnienie się Internetu w latach 90. XX w. jest wskazywane jako trzeci etap rozwoju technologii informacyjno-komunikacyjnych w turystyce w ujęciu globalnym, po komputerowych systemach rezerwacyjnych (lata 70.), i globalnych systemach dystrybucyjnych (lata 80.) (Buhalis 1998). Zmieniające się otoczenie powoduje konieczność „przeprojektowania" swojej roli przez podmioty z sektora publicznego zarządzające rozwojem turystyki, z uwzględnieniem zastosowania technologii informacyjno-komunikacyjnych (Buhalis, Deimezi 2004). W Polsce ich rola przede wszystkim Internetu, w gromadzeniu, przetwarzaniu i udostępnianiu informacji turystycznej zaczęła zwiększać się w pierwszej dekadzie XXI w. (Gaworecki 2007; Merski i in. 2008). Oprócz źródeł 
osobowych i wydawniczych zaczęto udostępniać elektroniczne, za pośrednictwem których znacznie rozszerzył się dostęp do informacji i usług turystycznych (Ziółkowski 2007; Pawlusiński 2008; Nalazek 2010). Stały się one kolejnym pośrednikiem między nadawcą a odbiorcami w systemie informacji turystycznej (Ziółkowski 2007). Co więcej, umożliwiły udzielanie informacji w formie multimedialnej bez ograniczeń czasowych i przestrzennych, bieżące jej aktualizowanie, a także zmniejszenie kosztów jej utworzenia, obsługi oraz dotarcia z nią do odbiorców (Buhalis 2008), również z uwzględnieniem potrzeb osób z niepełnosprawnościami (Zajadacz 2012).

Promocja i informacja turystyczna, dotyczące gminy, mogą być realizowane za pośrednictwem pojedynczych narzędzi lub systemu informacji turystycznej z różnorodnymi rozwiązaniami, analogowymi i cyfrowymi. Skuteczne jego działanie wymaga zastosowania innowacji, zarówno technologiczno-procesowych (narzędzia elektroniczne), jak i organizacyjnych (obsługa klienta) (Panasiuk 2010). Koncepcja inteligentnej destynacji turystycznej (ang. smart tourism destination), łącząca się z założeniami miasta inteligentnego (ang. smart city), zakłada, że zastosowanie technologii informacyjno-komunikacyjnych ma kluczowe znaczenie (del Chiappa i in. 2015; Gretzel i in. 2015; Ivars-Baidal i in. 2017). Rozwiązania tego rodzaju umożliwiają i ułatwiają korzystanie $\mathrm{z}$ informacji, usług i infrastruktury w destynacji turystycznej, np. przez aplikacje mobilne, usługi geolokalizacyjne, rozwiązania z zakresu tzw. Internetu rzeczy (ang. Internet of things) (Gretzel i in. 2015). Obecnie, co należy podkreślić, narzędzia cyfrowe służą również do gromadzenia danych (ang. big data) o decyzjach i potrzebach turystów na podstawie ich aktywności, np. na stronach internetowych, w mediach społecznościowych, aplikacjach mobilnych. Mogą one zostać wykorzystane w zarządzaniu destynacją turystyczną, np. w tworzeniu kolejnych informacji, usług lub atrakcji, również z zastosowaniem technologii informacyjno-komunikacyjnych (Ivars-Baidal i in. 2017).

Warto zwrócić uwagę na jeszcze jedno zagadnienie. Podmiot zarządzający rozwojem destynacji turystycznej może tworzyć wartość dodaną dla konsumenta i kształtować jego doświadczenie jako turysty za pośrednictwem narzędzi cyfrowych, jak media społecznościowe, technologia NFC lub mobilna, usługi geolokalizacyjne, rzeczywistość rozszerzona (Neuhofer i in. 2012; Neuhofer i in. 2014). Co więcej, obecnie sam turysta może współtworzyć swoje własne doświadczenie za pośrednictwem narzędzi cyfrowych, również podczas pobytu w destynacji turystycznej (Neuhofer i in. 2012). Narzędzia te, czego przykładem jest strona internetowa, zgodnie z ewolucyjnym modelem implementacji technologii informacyjno-komunikacyjnych, systematycznie stają się coraz bardziej dopasowane do celów podmiotu zarządzającego rozwojem turystyki i potrzeb konsumentów (Yuan i in. 2006).

Znaczenie korzystania $\mathrm{z}$ technologii informacyjno-komunikacyjnych podczas wyjazdu turystycznego jest podkreślone w koncepcji smart tourism. Aktywność ta może pozytywnie oddziaływać na doświadczenie turysty, ponieważ w ten sposób 
zyskuje on dostęp do różnorodnej informacji oraz zindywidualizowanych, interaktywnych i uwzględniających geolokalizację usług, np. przez urządzenia przenośne, media społecznościowe, technologie NFC, RFID lub beacon (Gretzel i in. 2015). To z kolei nawiązuje do koncepcji gospodarki doświadczeń (Darmer in. 2013; Sundbo i in. 2013) i trendu prosumenckiego (Tapscott 2010).

\section{Cele i metody badań}

W artykule omówiono wyniki badań obejmujące diagnozę zastosowania technologii informacyjno-komunikacyjnych w promocji i informacji turystycznej przez samorządy gminne w województwie małopolskim. Celem badań na tym etapie było rozpoznanie zakresu wykorzystania technologii informacyjno-komunikacyjnych, co umożliwiło scharakteryzowanie kierunków działań oraz wskazanie zmian i różnic je cechujących.

Badania przeprowadzono w dwóch etapach. Najpierw przeprowadzono inwentaryzację i na jej podstawie opracowano zestawienie narzędzi cyfrowych dla wszystkich 182 gmin. W celu uchwycenia dynamiki zmian przeprowadzono inwentaryzację dwukrotnie: w 2013 r. i 2018 r. (por. Pawłowska 2014, 2015, 2016). Objęto nią 182 oficjalne strony internetowe urzędów gmin, dwa sklepy internetowe z aplikacjami mobilnymi (Google Play Store i App Store), a także dwa systemy informacyjne: Samorządowy Informator SMS (SISMS) i System Informacji Lokalnej (SIL24).

Następnie przeanalizowano opracowane zestawienie w ujęciu ilościowym i jakościowym. Na podstawie wyników badań z 2018 r. przeprowadzono klasyfikację gmin z uwzględnieniem (1) podstawowej użyteczności i (2) zakresu informacji turystycznej na oficjalnych stronach internetowych urzędów gmin, (3) zróżnicowania ogółu narzędzi cyfrowych w promocji i informacji turystycznej gmin i (4) zróżnicowania aplikacji mobilnych z informacją turystyczną o gminach. Ocenę poszczególnych cech przeprowadzono z zastosowaniem przyjętych kryteriów i wag. Za spełnienie kryterium oceny przyznano gminie punkty cząstkowe, przy czym maksymalna łączna wartość wskaźnika punktowego, jaką gmina mogła uzyskać, wyniosła 1 , a minimalna 0 . Znaczenie poszczególnych cech dla ostatecznej oceny nie jest równoważne, dlatego zdecydowano się na zastosowanie wag. Gminy sklasyfikowano według pięciu przedziałów wskaźnika punktowego $(0,01-0,20$; $0,21-0,40 ; 0,41-0,60 ; 0,61-0,80 ; 0,81-1,00)$. Wyniki klasyfikacji przedstawiono w formie kartogramów. 


\section{Wyniki badań}

\section{Podstawowa użyteczność oficjalnych stron internetowych urzędów gmin}

Podstawową użyteczność oficjalnych stron internetowych urzędów gmin w 2013 i 2018 r. przedstawiono na ryc. 1 . Od 2013 r. do 2018 r. blisko połowa urzędów gmin utworzyła nową wersję oficjalnej strony internetowej (47\%). Cechą charakterystyczną analizowanych stron internetowych był szeroki zakres użytych rozwiązań spowodowany rozwojem technologii programistycznych. Począwszy od prostych rozwiązań projektowych, jak układ na formacie tabeli, przez wykorzystanie technologii Adobe Flash, obecnie wycofywanej z użycia, m.in. ze względu na luki w bezpieczeństwie, po najnowsze rozwiązania, jak technologia HTML5. To zróżnicowanie uświadamia, że tworzenie strony internetowej urzędu gminy, a patrząc szerzej również np. aplikacji mobilnej, nie powinno być zadaniem jednorazowym. Kolejną cechą charakterystyczną była większa dbałość o szatę graficzną strony internetowej w 2018 r. niż w 2013 r. Szablony graficzne częściej nawiązywały do herbu i barw gminy lub do systemu identyfikacji wizualnej.

Pozycja wyniku wyszukiwania w Google Position in Google search engine results

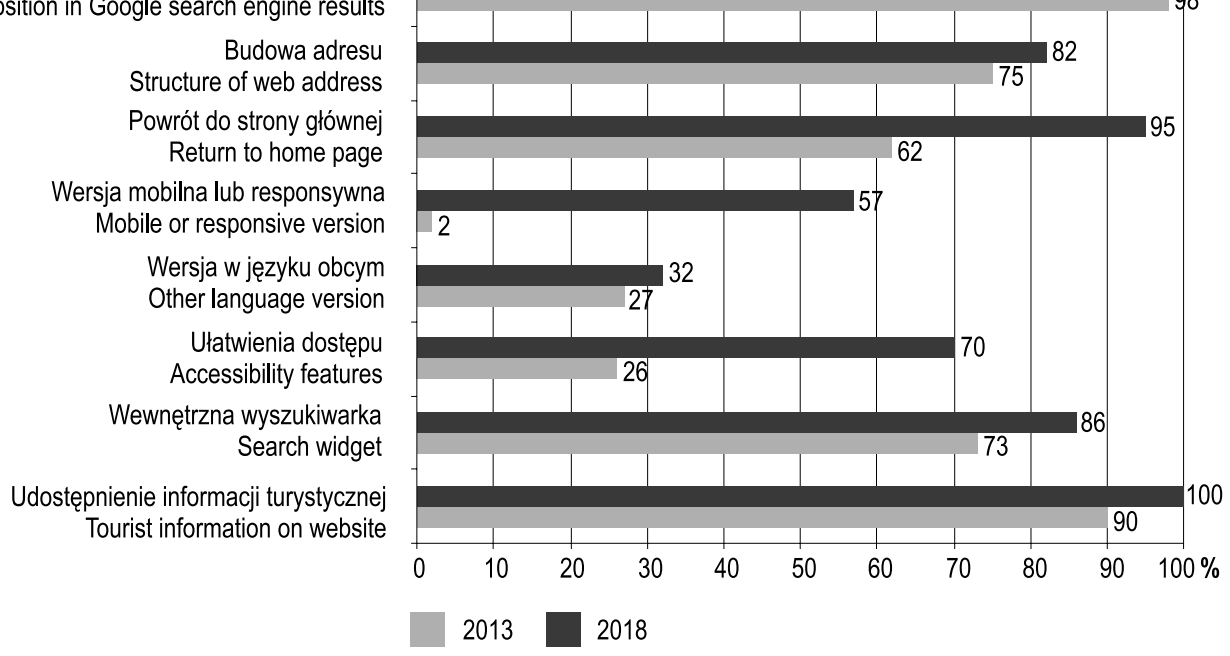

Ryc. 1. Podstawowa użyteczność oficjalnych stron internetowych urzędów gmin w 2013 i 2018 r. $(\%)$

Fig. 1. Basic functionalities of official websites of commune offices in 2013 and 2018 (\%) 
W 2018 r. zdecydowana większość stron internetowych działała prawidłowo, jednak nie były one całkowicie pozbawione błędów (tab. 1). Ponad $80 \%$ stron internetowych w 2018 r. spełniło kryterium pierwszego wyniku wyszukiwania w Google po wpisaniu nazwy gminy. Odsetek ten był niższy niż w 2013 r. (98\%). Różnice w indeksowaniu w wyszukiwarce mogą być związane z odpłatną reklamą, np. komercyjnego serwisu internetowego o regionie turystycznym lub obiektu noclegowego na terenie gminy, a także z pozycjonowaniem ze względu na udostępnione treści lub częstość odwiedzin. Również ponad $80 \%$ z nich miało adres w prostej domenie złożonej z dwóch poziomów (np. nazwagminy.pl lub .eu), co z kolei uległo zwiększeniu w porównaniu z 2013 r. (75\%). Ze względu na upowszechnienie się w Polsce urządzeń przenośnych z dostępem do Internetu znacząco zwiększyła się liczba stron internetowych w wersji mobilnej lub responsywnej (o 55\%). Natomiast te utworzone ponad dekadę temu, kiedy nie istniała jeszcze koncepcja responsywności, tracą na użyteczności w tzw. erze postpecetowej, kiedy ludzie „konsumują treści” na urządzeniach o różnych rozmiarach ekranów. Z kolei na blisko $1 / 3$ stron internetowych była dostępna wersja w języku obcym, głównie dla ośrodków turystycznych i większych miast. Najczęściej stosowanym ułatwieniem dostępu była funkcja powiększenia liter i zwiększenia kontrastu dla osób niedowidzących (70\%). Nieliczne wersje do odsłuchu działały w ograniczonym zakresie.

W tworzeniu stron internetowych mają znaczenie zasady projektowania doświadczenia użytkownika (ang. user experience), które umożliwiają dostosowanie projektu do sposobu korzystania przez odbiorcę. Na kilkunastu stronach internetowych zastosowano tzw. intro dzielące stronę główną na podstrony, np. „Strefa turystyczna” oraz „Strefa mieszkańca”, i kierujące użytkownika od razu do interesujących go treści. Rozwiązanie to było dostępne dla: Bochni (m.), Czorsztyna, Kościeliska, Krynicy-Zdroju, Łącka, Łużnej, Muszyny, Poronina, Rabki-Zdroju, Ropy, Rytra i Uścia Gorlickiego. Są to w większości gminy będące ośrodkami turystycznymi, niektóre o funkcji uzdrowiskowej. Na każdej stronie internetowej udostępniono informację turystyczną (ryc. 1) z co najmniej jednej z badanych kategorii (ryc. 3). Na nieco ponad połowie z nich (59\%) znajdowała się wyraźnie wyodrębniona zakładka (lub baner) z informacją turystyczną, np. „Turystyka”, „Turystyka i rekreacja”, „Turystyka w naszej gminie” itp. W kilku przypadkach kierowała ona użytkownika do odrębnego tematycznego serwisu internetowego lub strony internetowej w subdomenie urzędu gminy. Zwiększyła się liczba stron internetowych z funkcją powracania do strony głównej przez kliknięcie w umowne oznaczenie strony startowej, herb lub logotyp gminy (95\%) umieszczone w lewym górnym rogu, a także tych z wewnętrzną wyszukiwarką (86\%). W górnej lub bocznej części stron internetowych znajdowało się menu nawigacyjne z zakładkami tematycznymi. Na większości z nich zastosowano tzw. paginację ułatwiającą korzystanie z treści archiwalnych, a na nielicznych tzw. przycisk wzywający do działania (ang. call to action bar), np. „Odwiedź”, „Kliknij”, „Dołącz do nas na Facebooku”. 
Tab. 1. Błędy zidentyfikowane na oficjalnych stronach internetowych urzędów gmin Table 1. Problems and errors identified on official websites of commune offices

\begin{tabular}{|c|c|}
\hline Błędy „techniczne” / „Technical” problems and errors & Błędy „estetyczne” / „Aesthetic” problems and errors \\
\hline $\begin{array}{l}\text { - Niepoprawnie zdefiniowane adresy/hiperłącza poszcze- } \\
\text { gólnych elementów, np. banerów informacyjnych } \\
\text { i reklamowych, } \\
\text { - Niepoprawne działanie niektórych elementów, np. } \\
\text { podstrony, wyszukiwarki wewnętrznej, obrazu z kamery } \\
\text { zewnętrznej, wirtualnego spaceru, } \\
\text { - Brakujące zasoby strony internetowej, np. arkusze } \\
\text { stylów, grafiki, czcionki, } \\
\text { - Błędy programistyczne w skryptach Javascript, } \\
\text { - Meta tag blokujący indeksowanie przez wyszukiwarkę } \\
\text { Google, } \\
\text { - Wolne ładowanie przez brak optymalizacji kodów } \\
\text { źródłowych, } \\
\text { - Niewłaściwe działanie wersji mobilnej lub responsywnej, } \\
\text { - Niewłaściwe działanie wersji językowej i/lub niekom- } \\
\text { pletne tłumaczenia, } \\
\text { - Brak treści na podstronie i/lub treści powielone na kilku } \\
\text { podstronach, } \\
\text { - „Nieintuicyjne” rozmieszczenie poszczególnych } \\
\text { elementów, np. wewnętrznej wyszukiwarki lub funkcji } \\
\text { zmiany języka w dolnej części, } \\
\text { - Konieczność instalacji dodatkowego oprogramowania } \\
\text { lub brak kompatybilności rozwiązania z przeglądarką } \\
\text { internetową zmniejszające użyteczność treści, } \\
\text { - Niepoprawne działanie, np. wirtualnych spacerów } \\
\text { w technologii Adobe Flash, z powodu „starzenia } \\
\text { się” technologii internetowych i/lub zaniechania ich } \\
\text { rozwoju. }\end{array}$ & $\begin{array}{l}\text { - Nadmiar hiperłączy, } \\
\text { - Nadmiar banerów informacyjnych i reklamowych, } \\
\text { - Nadmiar i nieczytelne formatowanie tekstu, } \\
\text { - Niedostateczna jakość materiałów graficznych, } \\
\text { - Niedostateczna jakość materiałów kartograficznych, } \\
\text { - Niedostateczna jakość treści audiowizualnych, } \\
\text { - Stosowanie zbyt ozdobnych czcionek. }\end{array}$ \\
\hline
\end{tabular}

Ocenę podstawowej użyteczności oficjalnych stron internetowych urzędów gmin przedstawiono na ryc. 2. Aż 71\% gmin uzyskało ocenę bardzo wysoką i wysoką. Relatywnie niewiele gmin uzyskało ocenę średnią (22\%), niską i bardzo niską (5\%). Podobne zależności charakteryzują zakres informacji turystycznej na oficjalnych stronach internetowych oraz zróżnicowanie narzędzi cyfrowych w promocji i informacji turystycznej gminy, omówione poniżej.

Uogólniając, gminy ocenione bardzo wysoko i wysoko w tych trzech przypadkach można podzielić na trzy grupy. W jednej z nich są miasta, również te będące siedzibami gmin miejsko-wiejskich, w których w różnym stopniu rozwija się turystyka. Przykładami są: Andrychów, Biecz, Bochnia (m.), Chrzanów, Dobczyce, Gorlice (m.), 


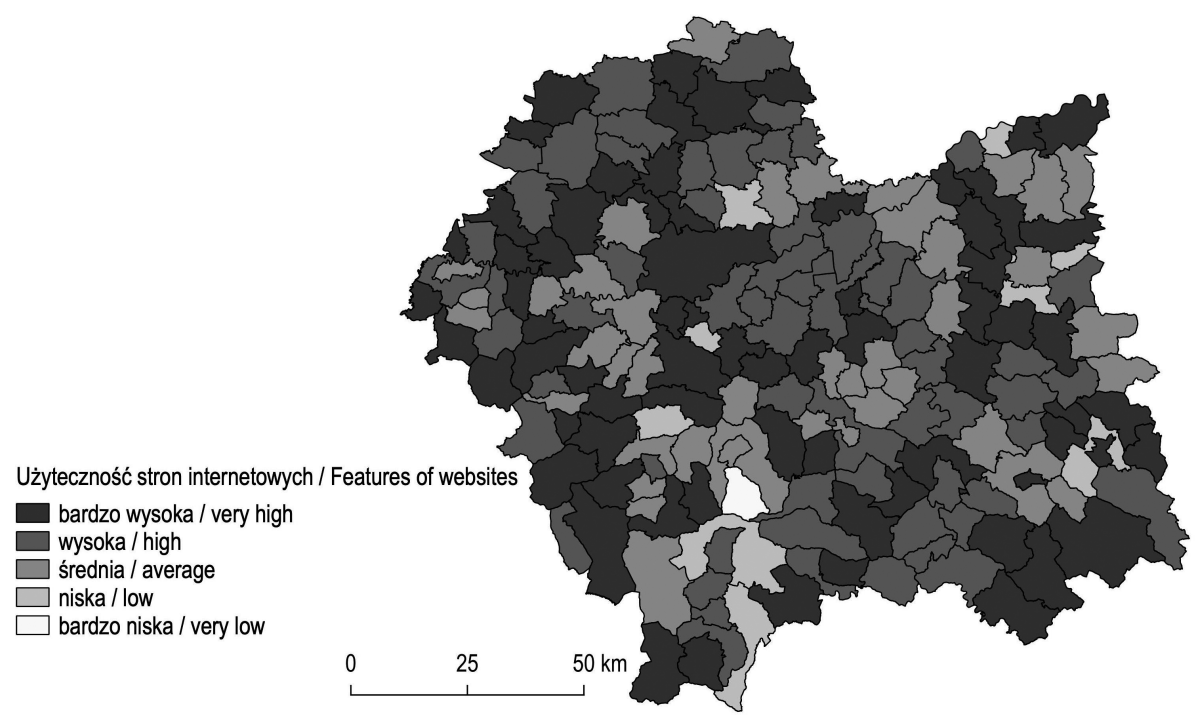

Ryc. 2. Ocena podstawowej użyteczności oficjalnych stron internetowych urzędów gmin w 2018 r.

Fig. 2. Evaluation of basic features of official websites of commune offices in 2018

Kraków, Miechów, Nowy Sącz, Wieliczka, Zakopane' ${ }^{1}$ Kolejną grupą są gminy miejsko-wiejskie i wiejskie w strefach podmiejskich aglomeracji Krakowa, np.: Babice, Krzeszowice, Mogilany, Skała, Świątniki Górne, Wielka Wieś, Zielonki, oraz Tarnowa, np.: Pleśna, Tuchów, Wojnicz, Zakliczyn, Żabno, a także te w pobliżu mniejszych ośrodków miejskich, jak Bochnia, np. Nowy Wiśnicz, i Brzesko, np. Czchów i Gnojnik, przez co również są one ośrodkami wypoczynku jednodniowego. Są to gminy położone na obszarach atrakcyjnych turystycznie, jak Pogórza: Ciężkowickie (powiat tarnowski), Wielickie (bocheński i wielicki) i Wiśnickie (bocheński i brzeski) i Wyżyna Krakowsko-Częstochowska (krakowski i olkuski). Natomiast w trzeciej grupie jest większość gmin z regionów turystycznych w Tatrach i Kotlinie Orawsko-Nowotarskiej, Gorcach i Pieninach oraz na Pogórzu Rożnowskim i w Beskidach: Małym, Niskim, Sądeckim, Wyspowym i Żywieckim (powiaty: gorlicki, limanowski, myślenicki, nowosądecki, nowotarski, tatrzański, wadowicki).

\footnotetext{
${ }^{1}$ Brak Oświęcimia może być spowodowany błędami programistycznymi na stronie internetowej urzędu gminy (liczba błędów z dn. 8.03.2018 r. wynosiła 12, np. brakujące pliki CSS) lub meta tagiem blokującym jej indeksowanie przez wyszukiwarkę Google.
} 
Oceny średnie i niższe uzyskały przede wszystkim gminy wiejskie w północnej części województwa małopolskiego (powiaty: brzeski, dąbrowski i proszowicki) oraz pojedyncze gminy wiejskie na obszarach górskich (powiaty: gorlicki, limanowski i nowotarski). Powodem był przede wszystkim brak trzech funkcji: ułatwień dostępu, wersji mobilnej lub responsywnej oraz wersji w języku obcym.

\section{Zakres informacji turystycznej na oficjalnych stronach internetowych urzędów gimin}

Zakres informacji turystycznej na oficjalnych stronach internetowych urzędów gmin w 2013 i 2018 r. przedstawiono na ryc. 3. Zwiększyła się liczba stron internetowych z udostępnioną informacją turystyczną z każdej badanej kategorii. W 2018 r. na 95\% z nich znajdowała się informacja o walorach turystycznych. Była ona zróżnicowana pod względem formy i treści, jednak zawierała co najmniej podstawowy wykaz, a najczęściej były to szczegółowe opisy. Wysoki odsetek dotyczył też materiałów fotograficznych (89\%); najczęściej w formie galerii zdjęć lub zdjęć oblanych tekstem, rzadziej tzw. karuzeli. Informację o usługach noclegowych zamieszczono na blisko $70 \%$ stron internetowych, a o innych usługach, np. gastronomicznych, na ponad $90 \%$ z nich. Ponadto udostępniono kalendarze organizowanych wydarzeń (64\%) i dane teleadresowe, hiperłącza lub banery do odrębnych stron internetowych ośrodków kultury (83\%). Na 1/5 z nich takie rozwiązanie zastosowano dla punktu Małopolskiego Systemu Informacji Turystycznej (MSIT) lub innej, lokalnej sieci. Aż dwukrotnie zwiększyła się liczba stron internetowych z materiałami „do pobrania"; najczęściej były to foldery promocyjne lub mapy tras pieszych i rowerowych. $\mathrm{Na}$ niektórych stronach internetowych zamieszczono fotografie w wysokiej rozdzielczości, opracowania monograficzne o gminie lub audioprzewodniki (Bobowa, Brzesko, Olkusz).

Wyniki oceny zakresu informacji turystycznej na oficjalnych stronach internetowych urzędów gmin na podstawie danych z 2018 r. przedstawiono na ryc. 4. Zdecydowana większość gmin udostępniła bardzo szeroki i szeroki zakres informacji turystycznej (82\%). Z kolei średni zakres informacji turystycznej charakteryzował $15 \%$ gmin, a niższy niż średni zaledwie $4 \%$.

\section{Zróżnicowanie narzędzi cyfrowych w promocji i informacji turystycznej gmin}

Zróżnicowanie narzędzi cyfrowych w promocji i informacji turystycznej gmin w 2013 i 2018 r. przedstawiono na ryc. 5. W 2018 r. wszystkie urzędy gminy udostępniły co najmniej jedną kategorię informacji turystycznej na oficjalnych stronach internetowych, 
Informacja o walorach turystycznych Information about tourist attractions

Fotografie / Pictures

Informacja o usługach noclegowych Information about accomodation services Informacja o innych usługach Information about other services Materiały „do pobrania" Downloadable content

Kalendarz wydarzeń / Events calendar

Informacja o punkcie informacji turystycznej Information about tourist information centre Informacja o ośrodku kultury Information aboout local culture centre

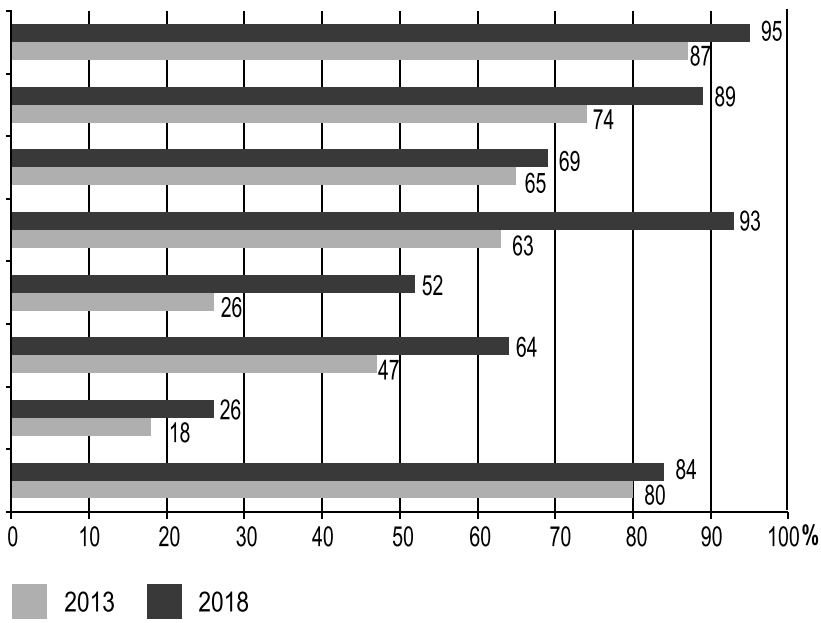

Ryc. 3. Zakres informacji turystycznej na oficjalnych stronach internetowych urzędów gmin w 2013 i 2018 r. (\%)

Fig. 3. Range of a tourist information on official websites of commune offices in 2013 and $2018(\%)$

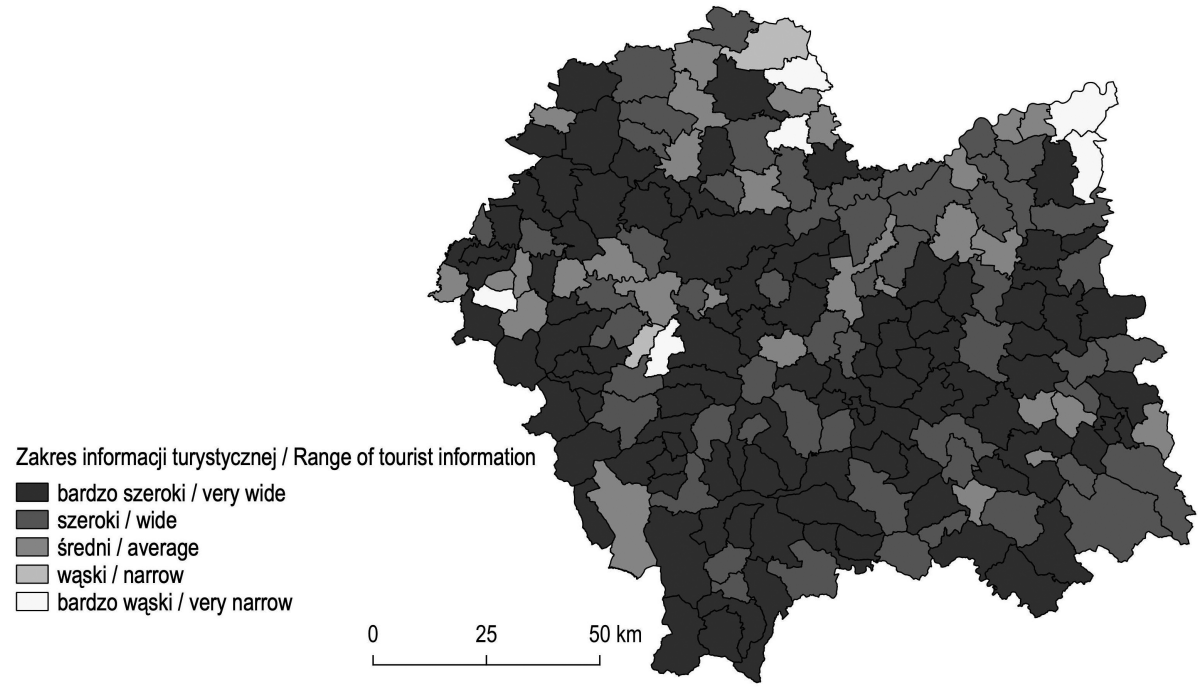

Ryc. 4. Ocena zakresu informacji turystycznej na oficjalnych stronach internetowych urzędów gmin w 2018 r.

Fig. 4. Evaluation of the range of a tourist information on official websites of commune offices in 2018 
co nie cechowało ich w 2013 r. Odrębny tematyczny serwis internetowy był dostępny dla $70 \%$ gmin. Zwiększyła się liczba aplikacji mobilnych z informacją turystyczną o gminach, z 30\% w 2013 r. do 80\% w 2018 r. Pośrednim źródłem informacji turystycznej był system powiadamiania sms, dostępny dla prawie wszystkich gmin (99\%). Wzrosła aktywność w serwisie społecznościowym Facebook, ponieważ konto z treściami promocyjno-informacyjnymi prowadziło $60 \%$ urzędów gmin. Zmniejszyła się natomiast liczba wirtualnych spacerów z $57 \%$ do $30 \%$, co może łączyć się ze „starzeniem się” technologii Adobe Flash. Obraz z kamery zewnętrznej udostępniono na blisko 1/4 stron internetowych w 2018 r., głównie ośrodków miejskich i narciarskich. Na stronach internetowych zamieszczano również fotografie lub filmy wykonane dronem, co jednak było jeszcze rzadko stosowane.

Wyniki oceny zróżnicowania narzędzi elektronicznych w promocji i informacji turystycznej gmin przedstawiono na ryc. 6. Dla blisko $70 \%$ gmin zróżnicowanie to było bardzo duże i duże, średnie dla $21 \%$, zaś małe dla $10 \%$. Żadna gmina nie charakteryzowała się bardzo małym zróżnicowaniem.

Tematyczne serwisy internetowe w formie odrębnej strony internetowej lub subdomeny strony internetowej urzędu gminy działały w ramach MSIT dla gmin: Kraków, Nowy Sącz, Nowy Targ (m.), Oświęcim (m.), Tarnów (m.), Wadowice i Rabka-Zdrój, oraz w innych, lokalnych sieciach tego rodzaju, np. w Piwnicznej-Zdroju, Tokarni, Zatorze. Pozostałe gminy należące do MSIT miały własną podstronę w serwisie internetowym VisitMałopolska.pl, będącym jego częścią. Niektóre oddziały utworzyły konta w serwisie społecznościowym Facebook. Liczne tematyczne serwisy internetowe oraz aplikacje mobilne, co omówiono poniżej, utworzono w ostatnich latach w ramach współpracy gmin wiejskich i miejsko-wiejskich na rzecz rozwoju ponadlokalnych produktów turystycznych z systemem informacji turystycznej. Współpraca ta odbywała się w lokalnych grupach działania, rzadziej w organizacjach turystycznych, lub partnerstwach innego rodzaju. Szczególnie były aktywne w tym zakresie gminy z powiatów: chrzanowskiego, krakowskiego, myślenickiego, nowotarskiego, olkuskiego, oświęcimskiego, suskiego, tarnowskiego i wadowickiego. Pod względem położenia geograficznego znajdują się one w sąsiedztwie aglomeracji Krakowa na Wyżynie Krakowsko-Częstochowskiej i Tarnowa na Pogórzu Ciężkowickim, będąc ośrodkami wypoczynku jednodniowego lub w regionach o długich tradycjach rozwoju turystyki, jak Gorce, Pieniny, Kotlina Orawsko-Nowotarska oraz Beskidy: Mały, Niski, Sądecki, Wyspowy i Żywiecki. Przykładami zrealizowanych projektów są ekomuzea nawiązujące do idei tzw. muzeum rozproszonego, trasy piesze, w tym tematyczne, nordic walking i umożliwiające grę terenową typu questing, oraz rowerowe. Niektóre z nich mają zasięg ponadregionalny w województwie małopolskim i śląskim lub na obszarach przygranicznych, ponieważ zrealizowano je z partnerami z Republiki Słowackiej. 
Oficjalna strona internetowa urzędu gminy

Official website of commune office

Tematyczny serwis internetowy Thematic portal

Aplikacja mobilna / Mobile application

System powiadamiania sms SMS alert system

Konto Facebook / Facebook account

Wirtualny spacer / Virtual tour

Obraz z kamery zewnętrznej

Live webcamera

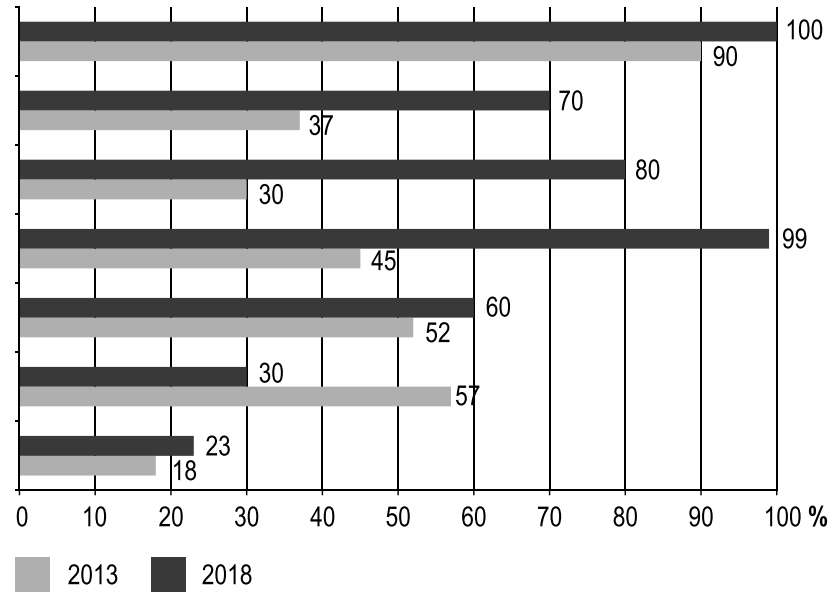

Ryc. 5. Zróżnicowanie narzędzi cyfrowych w promocji i informacji turystycznej gmin w 2013 i 2018 r. (\%)

Fig. 5. Diversity of digital tools in promotion and tourist information of communes in 2013 and $2018(\%)$

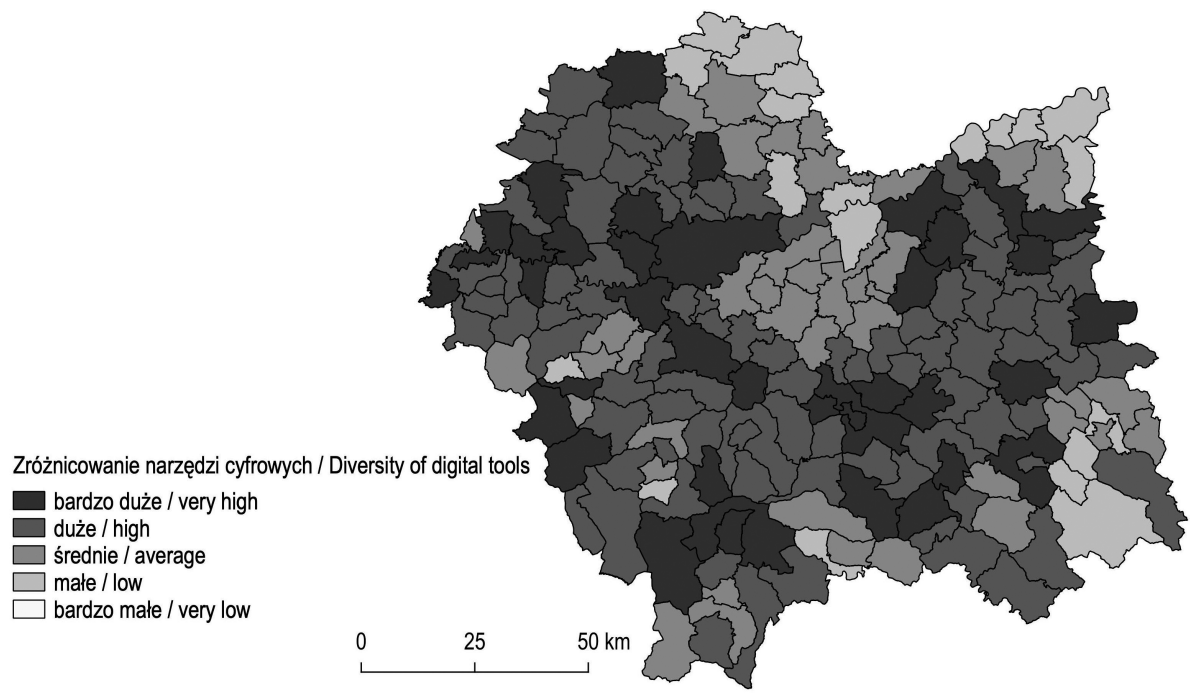

Ryc. 6. Ocena zróżnicowania narzędzi cyfrowych w promocji i informacji turystycznej gmin w 2018 r.

Fig. 6. Evaluation of the diversity of digital tools in promotion and tourist information of communes in 2018 


\section{Zróżnicowanie aplikacji mobilnych z informacją turystyczną o gminach}

W 2013 r. aplikacje mobilne z informacją turystyczną o gminach były dostępne dla $30 \%$, a w 2018 r. dla $80 \%$ z nich (ryc. 7). Zwiększyła się też liczba aplikacji mobilnych utworzonych przez podmioty inne niż samorządy gminne, np. samorządy powiatowe i wojewódzkie, w tym instytucje kultury (muzea), organizacje pozarządowe, parki narodowe, osoby prywatne i przedsiębiorstwa (ryc. 7). W konsekwencji liczba aplikacji ponadlokalnych (dla więcej niż jednej gminy) i tematycznych (dla jednej lub więcej niż jednej gminy) wzrosła o ok. 20\% (ryc. 8).

Wyniki oceny zróżnicowania aplikacji mobilnych z informacją turystyczną o gminach przedstawiono na ryc. 9. Bardzo duże i duże zróżnicowanie charakteryzowało $18 \%$ z nich. Przede wszystkim były to ośrodki miejskie z funkcją turystyczną, np. Bochnia (m.), Gorlice (m.), Kraków, Limanowa (m.), Mszana Dolna (m.), Oświęcim, Nowy Sącz, Nowy Targ (m.), Stary Sącz, Tarnów, Wadowice, Wieliczka i Zakopane. Oprócz aplikacji lokalnych i tematycznych w niektórych z nich były dostępne te przeznaczone do korzystania w muzeach oraz wyszukiwania połączeń transportu zbiorowego i kursów taksówek. Z aplikacji lokalnych można korzystać również w gminach wiejskich i miejsko-wiejskich będących ośrodkami wypoczynku jednodniowego, np. Babice, Lanckorona, Niepołomice, Olkusz, Zielonki, oraz uzdrowiskami, np. Rabka-Zdrój i Szczawnica.

Pod względem tego zróżnicowania najwięcej gmin uzyskało ocenę średnią (40\%). Ocenę tę kształtuje liczba aplikacji ponadlokalnych i tematycznych. Utworzono je dla gmin w ramach różnych projektów i partnerstw na rzecz rozwoju turystyki. Są to przede wszystkim gminy miejsko-wiejskie i wiejskie w regionach turystycznych

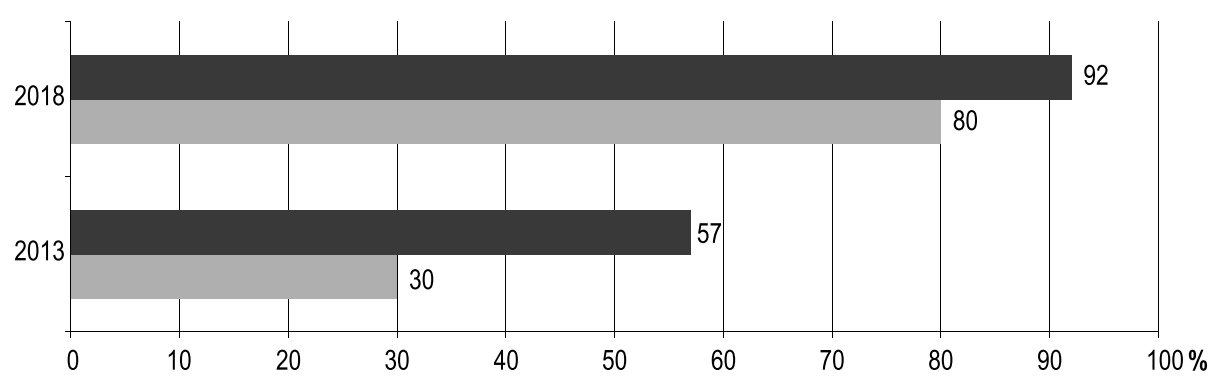

Aplikacje mobilne utworzone przez samorządy gminne i inne podmioty Mobile applications developed by local governments and other entities

Aplikacje mobilne utworzone przez samorządy gminne

Mobile applications developed by local governments

Ryc. 7. Aplikacje mobilne z informacją turystyczną o gminach w 2013 i 2018 r.

Fig. 7. Mobile applications containing tourist information about communes in 2013 and 2018 


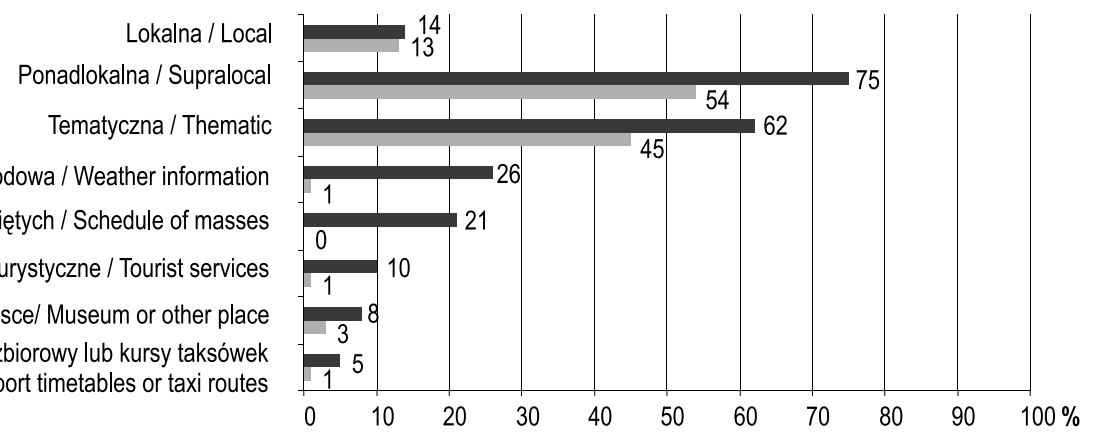

Informacja pogodowa / Weather information

Godziny mszy świętych / Schedule of masses

Usługi turystyczne / Tourist services

Muzeum lub inne miejsce/ Museum or other place

Transport zbiorowy lub kursy taksówek

Public transport timetables or taxi routes

Aplikacje mobilne utworzone przez samorządy gminne i inne podmioty Mobile applications developed by local governments and other entities

Aplikacje mobilne utworzone przez samorządy gminne

Mobile applications developed by local governments

Ryc. 8. Zróżnicowanie aplikacji mobilnych z informacją turystyczną o gminach w 2018 r.

Fig. 8. Diversity of mobile applications containing tourist information about communes in 2018

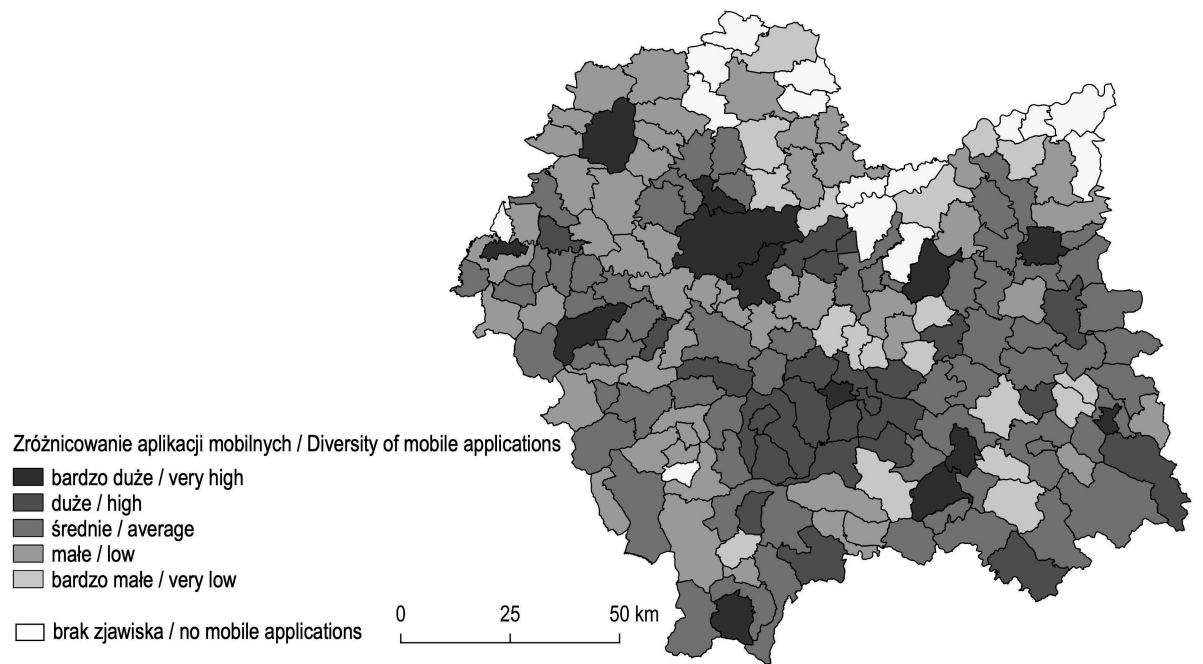

Ryc. 9. Ocena zróżnicowania aplikacji mobilnych z informacją turystyczną o gminach w $2018 \mathrm{r}$. Fig. 9. Evaluation of the diversity of mobile applications containing tourist information about communes in 2018 
w Beskidach i Tatrach (powiaty: gorlicki, limanowski, nowosądecki, wadowicki, tatrzański), na Pogórzach Rożnowskim i Wielickim oraz na Wyżynie Krakowsko-Częstochowskiej. Aplikacje te mogą być używane podczas rekreacji i aktywności fizycznej, np. na szlakach górskich, trasach rowerowych i nordic walking, w grach terenowych, jak questing, poznawania walorów turystycznych określonego rodzaju, np. architektura drewniana, rzemiosło tradycyjne, uroczyska, lub zwiedzania regionu, np. Orawa i Podhale.

Niektóre aplikacje mobilne połączono z wykorzystaniem QR kodów, np. w Beskidzie Wyspowym, na Pogórzach Ciężkowickim i Rożnowskim oraz na Wyżynie Krakowsko-Częstochowskiej w Ojcowskim Parku Narodowym. W jednej z aplikacji mobilnych w Krakowie zastosowano nadajniki beacon w technologii Bluetooth, a w aplikacji Tatrzańskiego Parku Narodowego QR kody i technologię zbliżeniową NFC. Kolejna aplikacja mobilna dla Krakowa z opisem dziewięciu tematycznych tras zwiedzania, nawigacją GPS i audioprzewodnikiem była dopasowana do potrzeb osób z niepełnosprawnościami. Pojedyncze narzędzia tego rodzaju umożliwiały korzystanie z rzeczywistości wirtualnej, np. w gminach powiatu limanowskiego i Dolnym Kubinie na Słowacji. W Wadowicach aplikacja mobilna była dostępna do wypożyczenia w punkcie informacji turystycznej w zestawie z tabletem.

\section{Podsumowanie}

Na podstawie przeprowadzonych badań można ocenić działania samorządu gminnego z województwa małopolskiego w zakresie promocji i informacji turystycznej z wykorzystaniem technologii informacyjno-komunikacyjnych jako liczne i zróżnicowane. Podstawowe narzędzie promocji i źródło informacji turystycznej, jakim są oficjalne strony internetowe, w zdecydowanej większości przypadków spełniają swoją rolę. Za ich pośrednictwem są udostępniane zróżnicowane treści i funkcje, nie tylko informacja tekstowa o walorach turystycznych, ale też np. materiały fotograficzne i wirtualne spacery. Jednak narzędzia te obejmują również szereg innych rozwiązań, jak tematyczne serwisy internetowe z rozbudowaną i zróżnicowaną informacją turystyczną oraz materiałami dodatkowymi, m.in. nagraniami audiowizualnymi, folderami i mapami „do pobrania” oraz tzw. planerami wycieczek. Kolejnymi przykładami są liczne aplikacje mobilne i systemy powiadamiania sms. Aplikacje mobilne, podobnie jak tematyczne serwisy internetowe, były nierzadko częścią regionalnego lub lokalnego systemu informacji turystycznej utworzonego przez samorząd gminny lub wojewódzki w ramach szerszej współpracy na rzecz rozwoju turystyki, jak np. ponadlokalny produkt turystyczny. Należy podkreślić w tym miejscu, że tworzenie w gminie oferty spędzania czasu wolnego jest obecnie łączone ze zróżnicowaną promocją i informacją turystyczną w przestrzeni wirtualnej i turystycznej. 
Wykorzystanie technologii informacyjno-komunikacyjnych w promocji i informacji turystycznej przez samorządy gminne w województwie małopolskim jest działaniem niezwykle dynamicznym. W momencie opracowania zestawienia dla 2013 r. wiele z rozwiązań dostępnych w 2018 r. było już na etapie projektowania i finansowania, w dużej mierze przy wykorzystaniu funduszy pochodzących z Unii Europejskiej. Aktywność ta oraz zmiany, które zaobserwowano podczas badań, np. utworzenie nowej wersji strony internetowej, aplikacji mobilnej lub konta w mediach społecznościowych (najczęściej był to Facebook, ale również Twitter lub Instagram) pokazują z kolei otwartość samorządu gminnego na potencjał nowych możliwości w komunikacji marketingowej oraz orientację na wdrażanie innowacji w tym zakresie.

Wyniki badań omówione w artykule są częścią rozprawy doktorskiej pt. „Wykorzystanie technologii informacyjno-komunikacyjnych (ICT) w działaniach promocyjnych i informacji turystycznej w gminach województwa małopolskiego". Finansowano je z Projektu „Doctus - Małopolski fundusz stypendialny dla doktorantów” Urzędu Marszałkowskiego Województwa Małopolskiego w latach 2012-2015 oraz ze środków DSC Wydziału Biologii i Nauk o Ziemi Uniwersytetu Jagiellońskiego w Krakowie w latach 2013-2016 (K/DSC/001787, 002377, 000913, 003025, 004021).

\section{Literatura}

Alejziak W., 2004, Polityka turystyczna [w:] R. Winiarski (red.), Nauki o turystyce, Studia i Monografie, 7, cz. 2, Akademia Wychowania Fizycznego im. Bronisława Czecha w Krakowie, Kraków, 41-94.

Altkorn J., 1998, Marketing w turystyce, Wydawnictwo Naukowe PWN, Warszawa.

Bartkowski J., Kowalczyk A., Swianiewicz P., 1990, Wtadze lokalne wobec reform systemu samorzqdowego [w:] J. Bartkowski, A. Kowalczyk, P. Swianiewicz (red.), Strategie wtad: lokalnych. Rozwój regionalny, Rozwój lokalny, Samorzad terytorialny, 21, Instytut Gospodarki Przestrzennej, Uniwersytet Warszawski, Warszawa, 185-203.

Borzyszkowski J., 2012, Organizacja $i$ zarzadzanie turystykq w Polsce, Wydawnictwo CeDeWu Sp. z o.o, Warszawa.

Bosiacki S., 2004, Marketing w turystyce [w:] R. Winiarski (red.), Nauki o turystyce, Studia i Monografie, 7, cz. 2, Akademia Wychowania Fizycznego im. Bronisława Czecha w Krakowie, Kraków, 43-54.

Brol R., 2009, Innowacyjnośćlokalnych jednostek terytorialnych [w:] R. Brol (red.), Gospodarka lokalna w teorii i praktyce, Prace Naukowe Uniwersytetu Ekonomicznego we Wrocławiu, 46, Wydawnictwo Uniwersytetu Ekonomicznego we Wrocławiu, Wrocław, 52-61. 
Buhalis D., 1998, Strategic use of information technologies in the tourism industry, Tourism Management, 5 (19), 409-421.

Buhalis D., Deimezi O., 2004, E-tourism developments in Greece: Information communication technologies adoption for the strategic management of the Greek tourism industry, Tourism and Hospitality Research, 5 (2), 103-130.

Buhalis D., 2008, Technologie informatyczne i telekomunikacyjnew turystyce [w:] L. Pender, R. Sharpley (red.), Zarzqdzanie turystykq, Polskie Wydawnictwo Ekonomiczne, Warszawa, 282-298.

Buhalis D., Leung D., Law R., 2011, eTourism: Critical information and communication technologies for tourism destinations [w:] Y. Wang, A. Pizam (red.), Destination marketing and management: Theories and applications, CAB International, Oxford, 205-224.

del Chiappa G., Baggio R., 2015, Analyzing the effects of a network structure, Journal of Destination Marketing \& Management, 4 (3), 145-150.

Darmer P., Sundbo J., 2013, Introduction to experience creation [w:] J. Sundbo, P. Darmer (red.), Creating experiences in the experience economy, Edward Elgar, Chettenham, 1-12.

Denek E., 2002, Turystyka a sadania i buḋ̇ety samorzqdu terytorialnego (gminnego, powiatowego i wojewódzkiego) [w:] G. Gołembski (red.), Kompendium wiedzy o turystyce, Wydawnictwo Naukowe PWN, Warszawa, 204-228.

Filipiak B., Milewski D., Panasiuk A., 2010, Zadania samoræqdu lokalnego w gospodarce turystycznej [w:] A. Panasiuk (red.), Informacja turystyczna, Wydawnictwo C.H. Beck, Warszawa, $15-35$.

Gaworecki W.W., 2007, Turystyka, Polskie Wydawnictwo Ekonomiczne, Warszawa.

Glińska E., Florek M., Kowalewska A., 2009, Wizerunek miasta. Od koncepcji do wdrożenia, Wolters Kluwer Polska, Warszawa.

Gretzel U., Sigala M., Xiang Z., Koo Ch., 2015, Smart tourism: Foundations and developments, Electronic Markets, 25 (3), 179-188.

Hjalager A.-M., 2010, A review of innovation research in tourism, Tourism Management, 31, 1-12. Holloway J.Ch., 1994, The business of tourism, Pitman Publishing, London.

Ivars-Baidal J.-A., Celdrán-Bernabeu M.A., Mazón J.-N., Perles-Ivars Á.F., 2017, Smart destinations and the evolution of ICTs: A new scenario for destination management?, Current Issues in Tourism, 22 (13), 1581-1600.

Kornak A.S., Rapacz A., 2001, Zarzqdzanie turystykq i jej podmiotami w miejscowości i regionie, Wydawnictwo Akademii Ekonomicznej im. Oskara Langego we Wrocławiu, Wrocław.

Kowalczyk A., 2010, Koncepcje turystycæne bliskie idei turystyki «równoważonej [w:] A. Kowalczyk, Turystyka zrównoważona, Wydawnictwo Naukowe PWN, Warszawa, 44-55.

Markowski T., Marszał T., 2005, Funkcje $i$ zarzadzanie obszarami metropolitarnymi, Samorząd Terytorialny, 7-8, 7-16.

Merski J., Piotrowski J.P., 2008, System informacji a ruch turystyczny, Almamer Wyższa Szkoła Ekonomiczna, Warszawa.

Mika M., 2014, Założenia i determinanty podtrzymywalności lokalnego rozwoju turystyki, Instytut Geografii i Gospodarki Przestrzennej Uniwersytetu Jagiellońskiego w Krakowie, Kraków. 
Nalazek M., 2010, Rola nowych technologii w informacji turystycznej [w:] D. Chudy-Hyski, M. Żemła (red.), Konsument na rynku turystycznym. Informacja turystyczna w Europie, Górnośląska Wyższa Szkoła Handlowa im. Wojciecha Korfantego, Katowice, 147-157.

Neuhofer B., Buhalis D., Ladkin A., 2012, Conceptualising technology enhanced destination experiences, Journal of Destination Marketing \& Management, 1 (1-2), 36-46.

Neuhofer B., Buhalis D., Ladkin A., 2014, A typology of technology-enhanced tourism experiences, International Journal of Tourism Research, 16 (4), 340-350.

Panasiuk A., 2010, Gospodarka turystyczna [w:] A. Panasiuk (red.), Informacja turystyczna, Wydawnictwo C.H. Beck, Warszawa, 50-63.

Pawlicz A., 2015, E-turystyka w obstudze uczestników turystyki i rekreacji [w:] B. Meyer (red.), Obstuga uczestników turystyki i rekreacji, Wydawnictwo Difin, Warszawa, 257-278.

Pawlusiński R., 2008, Informacja turystyczna [w:] W. Kurek (red.), Turystyka, Wydawnictwo Naukowe PWN, Warszawa, 181-184.

Pawłowska A., 2014, Informacja turystyczna 2.0. Zastosowanie technologii informacyjno-komunikacyjnych na rzecz poprawy dostępu do informacji turystycznej w województwie małopolskim, Episteme. Czasopismo Naukowo-Kulturalne, 2 (23), 179-99.

Pawłowska A., 2015, Innowacyjne sarzqdæanie rowwojem turystyki. Przykłady z wojewódætwa matopolskiego [w:] M. Romanowska, M. Chudzicki, R. Stasiak-Betlejewska (red.), Wspótczesne trendy w sarzqdæaniu organizacjq, Polskie Towarzystwo Ekonomiczne, Oddział w Częstochowie, Częstochowa, 75-81.

Pawłowska A., 2016, Aplikacje mobilne jako nowe naræędzie w informacji turystycznej. Wyniki badań przeprowadzonych w województwie matopolskim [w:] I. Miciuła, I. Nowakowska-Grunt (red.), Wybrane aspekty w zarzqdzaniu organizacjq wXXI w. Innowacje - Gospodarka - Spoteczeństwo, Wydawnictwo Naukowe Sophia, Katowice, 371-383.

Sundbo J., Sørensen F., 2013, Introduction to the experience economy [w:] J. Sundbo, F. Sørensen (red.), Handbook on the experience economy, Edward Elgar Publishing Limited, Cheltnecham, $1-20$.

Szromnik A., 2010, Marketing terytorialny. Miasto i region na rynku, Wolters Kluwer, Warszawa. Tapscott D., 2010, Cyfrowa dorostość. Jak pokolenie sieci smienia nasz świat, Wydawnictwa Akademickie i Profesjonalne, Warszawa.

Yuan Y.-L., Gretzel U., Fesenmaier D.R., 2006, The role of information technology use in American convention and visitors bureaus, Tourism Management, 27 (2), 326-341.

Zajadacz A., 2012, Turystyka osób niestyszacych - ujęcie geograficzne, Bogucki Wydawnictwo Naukowe, Poznań.

Ziółkowski R., 2007, Informacja w turystyce [w:] B. Meyer (red.), Obstuga ruchu turystycznego, Wydawnictwo Naukowe PWN, Warszawa, 95-106.

Aneta Pawtowska-Legwand

Uniwersytet Jagiellonski w Krakowie

Instytut Geografii i Gospodarki Præestræennej

ul. Gronostajowa 7, 30-387 Kraków

aa.pawlowska@uj.edu.pl 